\title{
CHANGING OF THE COLOUR OF CANNED STRAWBERRY DURING THE PROCESS OF STORAGE
}

\section{Zamorska}

Uman national university of horticulture

\begin{tabular}{l}
$\quad$ Key words: \\
Strawberries \\
Canned food \\
Colour \\
Intensity of the colour \\
Shade index \\
\hline \multicolumn{1}{c}{ Article history: } \\
Received 04.07.2018 \\
Received in revised form \\
25.07.2018 \\
Accepted 21.08.2018 \\
\hline
\end{tabular}

Corresponding author:

I. Zamorska

E-mail:

zil197608@gmail.com

\begin{abstract}
Berries of strawberry are a valuable raw material for the production of canned food, which quality largely depends on the colour. However, the colour of canned food changes during its storage, which is due to the loss of red pigment because of content reduction of anthocyanins, formation of brown pigments and discoloration from heavy metal contamination.

The purpose of the work was to determine the character of colour changes in canned strawberries during 6, 12 and 18 months of storage. The colour of preserve, jam, stew fruit and natural unbleached strawberry juice by measuring the optical density of the extractor on a photoelectrocolorimeter was studied. The intensity of the colour which characterizes the change in the intensity of light absorption under the wave length which corresponds to the maximum of absorption by natural pigments of fruit and berries and the shade which determines the change in the intensity of light absorption in the wave length area that characterizes accumulation of brown pigments was calculated.

It was found that there was an increase in shade indexes and intensity of colour during strawberries' storage due to enlargement of yellow-brown pigments in products. This process is especially expressed in strawberry juice, and least found in preserve (jam). Anthocyanin pigments were broken faster in canned strawberries of Honey variety, whereas they were more stable in products of Polka variety.

It was found that the duration of storage of canned strawberries correlates with the shade index $(r=0.71 \pm 0.05)$ and with the intensity of coloration of $(r=0.56 \pm 0.07)$. Shade index reflects the most fully the colour change of processing products from strawberry.

It was proved that the storage time should not exceed: natural unbleached strawberry juice more than 6 months, jam and stew fruit more than 12 months, and preserve 18 months, and storage duration of jam and stew fruit from strawberry berries of Polka variety until 18 months because of high resistance of anthocyanin pigments.
\end{abstract}

DOI: $10.24263 / 2225-2924-2018-24-4-24$ 


\section{ЗМІНА КОЛЬОРУ КОНСЕРВІВ 3 ЯГІД СУНИЦІ ВПРОДОВЖ ЗБЕРІГАННЯ}

\section{І.Л. Заморська}

Уманський національний університет садівництвва

Ягоди суниці садової - цүінна сировина для виробництва консервів, якість яких значною мірою залежить від кольору. Проте під час зберігання колір консервів змінюється, що зумовлено втратою червоного пігменту через зменшення вмісту антоціанів, формуванням коричневих пігментів $і$ знебарвленням від забруднення важкими металами.

Мета дослідження полягала в тому, щьоб встановити характер змін кольору консервів з ягід суниці протягом 6, 12 і 18 місяців зберігання. Колір варення, джемів, компотів $і$ соку суничного натурального неосвітленого досліджували иляхом вимірювання оптичної густини витяжки на фотоелектроколориметрі. Розраховували інтенсивність забарвлення, щз характеризує зміну інтенсивності поглинання світла за довжин хвиль, які відповідають максимумам поглинання природними пігментами плодів та ягід, i відтінок, який визначає зміну інтенсивності поглинання світла в області довжин хвиль, щэо характеризують накопичення коричневих пігментів.

Виявлено, щзо під час зберігання консервів із суниці спостерігається підвищення показників відтінку та інтенсивності забарвлення, щзо зумовлено наростанням жовто-коричневих пігментів у продукції. Найбільще цеей процес виражений у соку суничному, а найменше - у варенні. В консервах з ягід суниці сорту Хоней антоціанові пігменти руйнуються швидше, тоді як у продуктах з сорту Полка вони більи стійкі.

Встановлено, щзо тривалість зберігання консервів з ягід суниці корелює 3 показником відтінку $(r=0,71 \pm 0,05)$ та з інтенсивністю забарвлення $(r=$ $=0,56 \pm 0,07)$. Зміну кольору продуктів переробки з ягід суниці найбільш повно відображає показник відтінку.

Доведено, щуо тривалість зберігання не повинна перевищувати: соку суничного натурального неосвітленого - 6 міс., джему та компоту - 12 міс., а варення - 18 міс., а тривалість зберігання джему та компоту з ягід суниці сорту Полка - до 18 міс. через високу стійкість антоціанових пігментів.

Ключові слова: консерви, суниця, колір, інтенсивність забарвлення, відтінок, зберігання.

Постановка проблеми. Ягоди суниці садової — цінна сировина для виробництва компотів, джемів, варення, соків, пюре та інших видів продуктів, що є джерелом біологічно-активних сполук зі значним антиоксидантним потенціалом [1].

Однією 3 найбільш важливих характеристик якості продуктів переробки 3 ягід суниці, що впливає на вибір споживачів, є червоний колір [2], який визначається вмістом антоціанів і слугує основним джерелом їхньої антиоксидантної здатності. Проте серйозною проблемою $є$ зміна кольору консервів із суниці, що зумовлено втратою червоного пігменту через зменшення вмісту антоціанів, формуванням коричневих пігментів і знебарвленням від забруднення важкими металами [3]. 
Аналіз останніх досліджень і публікацій. Антоціани — це дуже нестійкі пігменти, що здатні легко розкладатися під дією різних факторів, а їхня стабільність визначається структурою і концентрацією пігменту, $\mathrm{pH}$, температурою, інтенсивністю освітлення, наявністю копігментів, іонів металів, ферментів, кисню, аскорбінової кислоти, цукру і продуктів їхнього розпаду, двоокису сірки [4; 5]. За даними M. Kopjar, V. Pilizota та ін. [3], антоціанові пігменти дуже чутливі до температури, а температурно-часовий режим обробки продукту істотно впливає на їхній вміст. Це відбувається внаслідок гідролізу антоціанів 3 утворенням більш дрібних фенольних сполук, антоціанідинів і цукру.

Неферментативним шляхом потемніння консервів 3 ягід суниці є реакція Майяра та карамелізація цукрів. В ягодах суниці наявні амінокислоти та цукри, під час нагрівання реактивна карбонільна група яких вступає в реакцію з нуклеофільною аміногрупою амінокислоти, внаслідок чого утворюються складні молекули, що легко вступають в реакцію 3 іншими сполуками з утворенням коричневих полімерних пігментів. За термічної обробки продукту відбувається карамелізація цукрів [6].

Проте основною причиною зміни кольору продуктів переробки з ягід суниці під час зберігання $\epsilon$ ферментативні реакції потемніння, що зумовлені активністю поліфенолоксидази та, меншою мірою, пероксидази. Для запобігання цьому процесу вказані ферменти слід інактивувати під час термічної обробки продукту [7; 8]. Відомо, що поліфенолокисидаза знаходиться в мембранах тилакоїдів хлоропластів, тоді як фенольні сполуки, в основному, зосереджені у вакуолях, i лише у разі пошкодження тканин та за наявності кисню буде відбуватися реакція окиснення, що призводить до утворення коричневих пігментів, ступінь якого залежить від загальної кількості фенольних сполук та активності ферменту. Активність поліфенолоксидази залежить від температури, а пік активності знаходиться за температури близько $50^{\circ} \mathrm{C} \mathrm{i} \mathrm{pH} \mathrm{5,5} \mathrm{[9].}$

Пероксидаза каталізує фенольні сполуки за наявності перекису водню, однак через вищі рівні кисню проти перекису водню та більшу термолабільність ферменту втрати антоціанів через окиснення пероксидазою незначні [10].

Виділення не вирішених раніше частин загальної проблеми. Умови зберігання продуктів переробки з ягід суниці повинні забезпечувати стабільність їхнього кольору. За даними L.F. Amaro, M.T. Soares [2], оптимальна температура для зберігання джему з суниці $-4^{\circ} \mathrm{C}$. Відомо, що під час зберігання джему з суниці впродовж місяця за температури $25^{\circ} \mathrm{C}$ вміст антоціанів в них істотно знижується. Втрати антоціанів зростають 3 підвищенням температури зберігання консервів [5]. Проте в науковій літературі не виявлено достатньої інформації щодо змін кольору консервів з суниці різних помологічних сортів протягом зберігання.

Мета статті: встановлення характеру змін кольору консервів 3 ягід суниці протягом 6, 12 і 18 місяців зберігання шляхом вимірювання оптичної густини витяжки.

Викладення основних результатів дослідження. Дослідження проводилося у 2014-2015 pр. 3 ягодами суниці сортів Дукат, Хоней та Полка. 3 підготовлених ягід виготовляли компоти, джеми і варення згідно з чинними технологічними інструкціями. Уварювали до вмісту сухих розчинних речовин: варення $-68 \%$, джем $-62 \%$. При виготовленні компотів підготовлені 
ягоди суниці заливали цукровим сиропом 3 концентрацією 68\%. Сік суничний натуральний неосвітлений отримували шляхом пресування м'язги. Готову продукцію фасували у скляну тару місткістю $250 \mathrm{~cm}^{3}$, пастеризували, герметизували та зберігали протягом 6, 12 i 18 міс. за температури $+2-4^{\circ} \mathrm{C}$, фіксуючи зміни кольору консервів за інтенсивністю забарвлення і відтінком методом поточних визначень 3 порівнянням візуальної оцінки.

Для оцінки кольору свіжих ягід суниці і консервів вимірювали оптичну густину спиртової витяжки зразків на фотоелектроколориметрі КФК-2 i розраховували: $U$ (інтенсивність забарвлення), що характеризує зміну інтенсивності поглинання світла за довжин хвиль, що відповідають максимумам поглинання природними пігментами плодів, та ягід і $O$ (відтінок), який визначає зміну інтенсивності поглинання світла в області довжин хвиль, що характеризують накопичення коричневих пігментів (при $\lambda=(400-460$ нм). Загальну інтенсивність забарвлення розраховували як суму оптичних густин: $U=\left(D_{420}+D_{520}\right)$. Відтінок — як відношення поглинання при 420 нм до поглинання при 520 нм $O=D_{420} / D_{520}$. Повторність досліду триразова.

Статистичний аналіз виконували за допомогою програми StatSoft STATISTICA 6.1.478 Russian, Enterprise Single User (2007).

Встановлено, що у свіжих ягодах суниці величина оптичної густини спиртової витяжки на різних довжинах хвиль практично не відрізняється (табл. 1). Розрахований показник відтінку у ягід суниці сорту Полка істотно нижчий проти інших, що свідчить про найменший вплив на забарвлення ягід жовто-коричневих пігментів. Натомість інтенсивність забарвлення у ягід суниці сорту Дукат суттєво перевищує дані інших помологічних сортів.

Таблиия 1. Інтенсивність забарвлення та відтінок свіжих ягід суниці (2014-2015pp.)

\begin{tabular}{|c|c|c|c|c|}
\hline \multirow{2}{*}{ Сорт } & \multicolumn{4}{|c|}{ Показник } \\
\cline { 2 - 5 } & $\begin{array}{c}\text { Величина оптичної густини на } \\
\text { довжині хвилі }\end{array}$ & Відтінок & $\begin{array}{c}\text { Інтенсивність } \\
\text { забарвлення }\end{array}$ \\
\cline { 2 - 5 } & $440 \mathrm{Hм}$ & $540 \mathrm{HM}$ & $O$ & $U$ \\
\hline Полка & 0,070 & 0,075 & 0,93 & 0,145 \\
\hline Хоней & 0,075 & 0,070 & 1,07 & 0,145 \\
\hline Дукат & 0,085 & 0,080 & 1,06 & 0,165 \\
\hline $\mathrm{HIP}_{05}$ & 0,005 & 0,005 & 0,01 & 0,01 \\
\hline
\end{tabular}

Дослідження змін інтенсивності забарвлення та відтінку консервів показали, що ці показники мають пряму залежність від тривалості зберігання (табл. 2). Так, після теплової обробки в готових консервах показник відтінку складав: для варення 1,3-1,5, джему - 1,1-1,4, компоту - 1,3-1,5, тоді як у сокові він не перевищив значення 0,8 і був максимально наближеним до аналогічного показника свіжих ягід. У компотах і варенні показник відтінку був дещо вищим проти аналогічних показників джему та значно вищим проти соку, що свідчить про більшу вираженість коричневих пігментів внаслідок теплової обробки.

Інтенсивність забарвлення консервів порівняно зі свіжими ягодами істотно знизилася, за винятком соку. Серед досліджуваних зразків консервів найбільше зниження спостерігалося у варенні, що зумовлено більш тривалою тепловою обробкою цього продукту. 
Через шість місяців зберігання встановлено підвищення показника відтінку консервів, що зумовлено наростанням жовто-коричневих пігментів у продукції. Особливо цей процес виражений у соку суничному. Аналогічні дані отримані і при розрахунку інтенсивності забарвлення, який показав збільшення на 0,05 одиниць за рахунок наростання жовто-коричневих пігментів, про що свідчить різке збільшення оптичної густини на довжині хвилі 440 нм. У розрізі помологічних сортів істотної різниці цих показників у різних видах консервів не виявлено.

Таблиия 2. Інтенсивність забарвлення та відтінку продуктів переробки з ягід суниці залежно від тривалості зберігання (2014-2015 рр.)

\begin{tabular}{|c|c|c|c|c|c|c|c|c|c|c|c|c|c|c|c|c|c|}
\hline & & & & & & & & Гриве & алість & зберіга & нНня & & & & & & \\
\hline & & На по & чатку 36 & еріга & ння & & 6 місяІ & & & & 12 міся & & & & 18 міся & & \\
\hline $\begin{array}{l}\frac{y}{2} \\
\text { 竞 } \\
\text { : }\end{array}$ & $\tilde{o}^{\circ}$ & 蛋 & 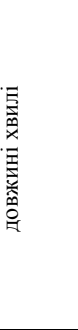 & 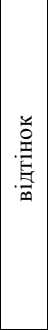 & 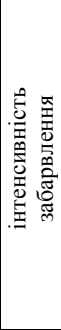 & 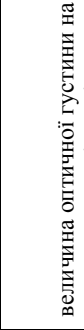 & 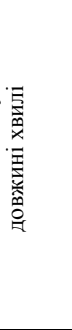 & 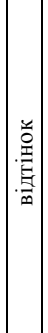 & 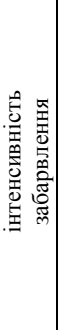 & 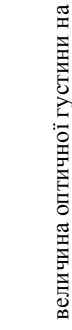 & 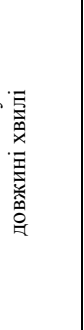 & 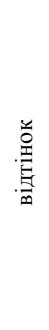 & 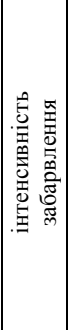 & 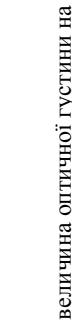 & 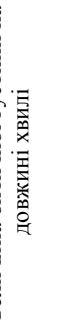 & 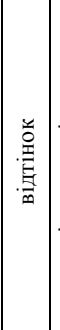 & 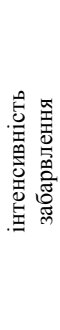 \\
\hline & & 440 нм & $540 \mathrm{HM}$ & $O$ & $U$ & $440 \mathrm{нм}$ & $540 \mathrm{Hм}$ & $O$ & $U$ & $440 \mathrm{HM}$ & 540 нм & $O$ & $U$ & 440 нм & $540 \mathrm{Hм}$ & $O$ & $U$ \\
\hline & Полка & 0,045 & 0,035 & 1,3 & 0,080 & \begin{tabular}{|l|l|}
0,050 \\
\end{tabular} & \begin{tabular}{|l|}
0,035 \\
\end{tabular} & 1,4 & 0,085 & 0,060 & \begin{tabular}{|l|}
0,040 \\
\end{tabular} & 1,5 & 0,100 & 0,080 & 0,045 & 1,77 & 0,12 \\
\hline Варення & Хоней & 0,045 & 0,030 & 1,5 & 0,075 & \begin{tabular}{|l|}
0,045 \\
\end{tabular} & 0,030 & & 0,075 & 0,070 & \begin{tabular}{|l|}
0,045 \\
\end{tabular} & 1,6 & 0,115 & 0,115 & 0,065 & 1,77 & 0,18 \\
\hline & Дукат & 0,020 & 0,015 & 1,3 & 0,035 & \begin{tabular}{|l|}
0,020 \\
\end{tabular} & 0,015 & & 0,035 & 0,050 & \begin{tabular}{|l|}
0,035 \\
\end{tabular} & 1,4 & 0,085 & 0,090 & 0,050 & 1,80 & 0,14 \\
\hline & Полка & 0,070 & 0,05 & & 0,120 & \begin{tabular}{|l|}
0,070 \\
\end{tabular} & \begin{tabular}{|l|}
0,050 \\
\end{tabular} & & 0,120 & 0,090 & \begin{tabular}{|l|}
0,055 \\
\end{tabular} & 1,6 & \begin{tabular}{|l|}
0,145 \\
\end{tabular} & 0,110 & 0,065 & 1,69 & $\begin{array}{ll}0,17 \\
\end{array}$ \\
\hline Джем & Хоней & 0,045 & 0,035 & 1,3 & 0,080 & \begin{tabular}{|l|}
0,050 \\
\end{tabular} & 0,035 & & 0,085 & 0,100 & \begin{tabular}{|l|}
0,050 \\
\end{tabular} & 2,0 & 0,150 & 0,150 & 0,075 & 2,00 & 0,22 \\
\hline & Дукат & 0,080 & 0,07 & 1,1 & 0,150 & \begin{tabular}{|l|}
0,100 \\
\end{tabular} & \begin{tabular}{|l|l|}
0,070 \\
\end{tabular} & 1,4 & 0,170 & 0,100 & \begin{tabular}{|l|}
0,070 \\
\end{tabular} & 1,4 & 0,170 & 0,100 & 0,050 & 2,00 & 0,15 \\
\hline & Полка & 0,045 & 0,035 & 1,3 & 0,080 & \begin{tabular}{|l|}
0,065 \\
\end{tabular} & \begin{tabular}{|l|l|}
0,035 \\
\end{tabular} & 1,8 & 0,100 & 0,065 & \begin{tabular}{|l|}
0,040 \\
\end{tabular} & 1,6 & 0,105 & 0,075 & 0,045 & 1,60 & 0,12 \\
\hline Компот & Хоней & 0,050 & 0,035 & 1,4 & 0,085 & \begin{tabular}{|l|}
0,060 \\
\end{tabular} & \begin{tabular}{|l|l|}
0,040 \\
\end{tabular} & & 0,100 & 0,090 & \begin{tabular}{|l|}
0,050 \\
\end{tabular} & 1,8 & 0,140 & 0,110 & 0,055 & 2,00 & \begin{tabular}{|l|}
0,17 \\
\end{tabular} \\
\hline & Дукат & 0,090 & 0,060 & 1,5 & 0,110 & \begin{tabular}{|l|}
0,100 \\
\end{tabular} & \begin{tabular}{|l|}
0,060 \\
\end{tabular} & 1,6 & 0,160 & 0,110 & \begin{tabular}{|l|}
0,060 \\
\end{tabular} & 1,8 & 0,170 & 0,120 & 0,060 & 2,00 & 0,18 \\
\hline $\mathrm{C}$ & & 0,070 & 0,075 & 0,8 & 0,155 & \begin{tabular}{|l|l|}
0,120 \\
\end{tabular} & \begin{tabular}{|l}
0,075 \\
\end{tabular} & & 0,190 & 0,150 & \begin{tabular}{|l|}
0,065 \\
\end{tabular} & 2,3 & 0,215 & 0,170 & 0,060 & 2,80 & 0,2 \\
\hline $\mathrm{HII}$ & & $\overline{0,}$ & & 0,02 & $0,0,07$ & 0,0 & & & 0,02 & $\overline{0,0}$ & 05 & 0,1 & \begin{tabular}{|l|l|}
0,02 \\
\end{tabular} & & 005 & \begin{tabular}{|l|l|}
0,1 \\
\end{tabular} & 0,02 \\
\hline
\end{tabular}

Зберігання суничних консервів протягом року зумовило наростання величини оптичної густини на довжині хвилі 440 нм на $0,10-0,50$ одиниць, натомість на довжині 540 нм вона зросла неістотно, а деяких випадках залишалася без змін. Розрахунок показника відтінку показав його зростання на $0,1-0,6$ одиниць залежно від виду продукту і помологічного сорту ягід.

Слід відмітити, що у варенні показник відтінку зріс на 0,1 , тоді як у джемах — на $0,2-0,6$, у компотах — на $0,2-0,3$, а в сокові - на 0,7 одиниць. Інтенсивність забарвлення консервів 3 суниці зросла на $0,015-0,065$ одиниць через істотне зростання величини оптичної густини на довжині хвилі 440 нм. Для соку суничного вказаний показник зріс до рівня 0,215. 3 огляду на отримані результати, що підтверджені візуально, через наростання жовто-коричневих пігментів у соку тривалість його зберігання слід обмежити до 6 місяців.

Серед досліджуваних зразків істотне наростання показника відтінку та інтенсивності забарвлення спостерігалося у джемах та компотах з ягід сорту Хоней: на 0,6 одиниць показника відтінку та на 0,065 інтенсивності забарвлення для джему i, відповідно, на 0,3 і 0,040 для компоту. Отже, антоціанові пігменти консервів з ягід цього сорту руйнуються швидше. 
Розрахунки показників відтінку та інтенсивності забарвлення консервів через 18 місяців зберігання показали зростання їхнього рівня. Це зумовлено активним наростанням жовто-коричневих пігментів у консервах, про що свідчить істотне збільшення величини оптичної густини на довжині хвилі 440 нм, тоді як на довжині хвилі 540 нм воно було несуттєвим.

Між показником відтінку консервів та тривалістю їхнього зберігання встановлено прямий сильний кореляційний зв'язок $(r=0,71 \pm 0,05)$, що описується рівнянням регресії: $y=-13,40+13,950 x$, де $y$ - тривалість зберігання консервів; $x$ - відтінок консервів (рис.).

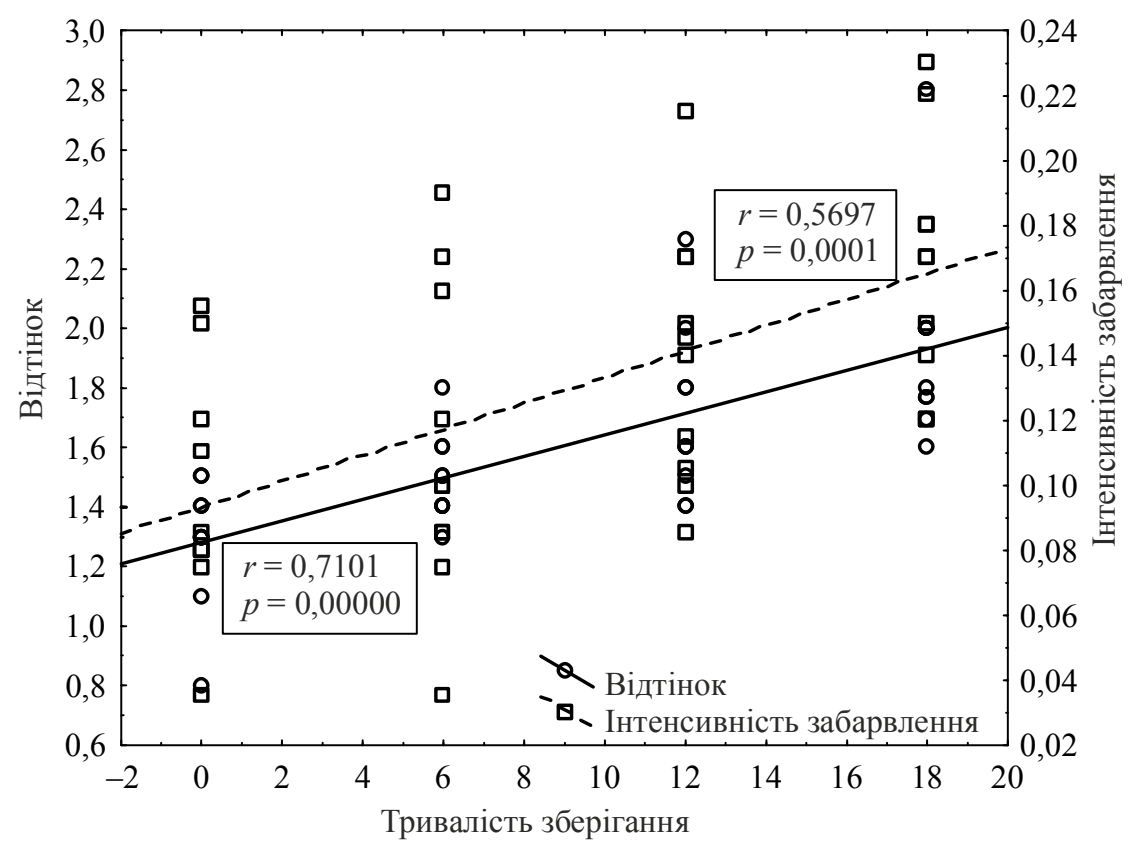

Рис. Кореляційна залежність відтінку та інтенсивності забарвлення консервів 3 суниці від тривалості їхнього зберігання

Прямий кореляційний зв'язок середньої сили виявлено між показником інтенсивності забарвлення консервів і тривалістю їхнього зберігання $(r=$ $=0,56 \pm 0,07)$, що описується рівнянням регресії: $y=-1,457+80,982 x$, де $y-$ тривалість зберігання консервів; $x$ - інтенсивність забарвлення.

Отримані результати вказують на значну різницю у розрахованих показниках серед досліджуваних зразків консервів, що підтверджено візуально: у джемах і компотах показник відтінку зріс до рівня 1,6-2,0, а інтенсивності забарвлення до $0,12-0,22$, тоді як у варенні, відповідно, до 1,8 та 0,18 .

У розрізі помологічних сортів істотне зростання показників відтінку та інтенсивності забарвлення виявлено у джемах і компотах з ягід суниці сортів Хоней та Дукат, тоді як для продуктів з ягід сорту Полка показник відтінку джемів не перевищив значення 1,69, інтенсивності забарвлення - 0,17, а компотів, відповідно, 1,6 та 0,12. Отримані результати свідчать про високу стійкість антоціанових пігментів ягід сорту Полка. 
Отже, джеми та компоти 3 ягід сортів суниці Хоней та Дукат потрібно зберігати не більше одного року, тоді як із ягід сорту Полка тривалість зберігання можна збільшити до 18 місяців. Варення можна зберігати протягом 18 місяців, оскільки наростання жовто-коричневих пігментів відбувається повільно i показники відтінку та інтенсивності забарвлення змінюються неістотно. Очевидно внаслідок більш тривалої теплової обробки варення відбулася повна інактивація ферментів поліфенолоксидази та пероксидази, діяльність яких призводить до ферментативного потемніння продуктів. Окрім цього, цей же фактор зумовлює підвищені втрати аскорбінової кислоти, продукти окиснення якої, як відомо, можуть спричиняти окиснення антоціанів до безбарвних сполук $[7 ; 11]$.

\section{Висновки}

Результати досліджень свідчать, що зміну кольору консервів з суниці найбільш повно відображає показник відтінку, який характеризує зміну інтенсивності поглинання світла в області довжин хвиль, що характеризують накопичення жовто-коричневих пігментів, утворення яких характерно під час зберігання консервів із суниці. Тривалість зберігання соку із суниці не повинна перевищувати 6 , джему та компоту - 12 , а варення - 18 місяців. Тривалість зберігання джемів та компотів з ягід суниці сорту Полка можна збільшити до 18 місяців через високу стійкість антоціанових пігментів.

\section{Література}

1. Gatkowska D. Physicochemical quality of selected strawberry jams with fructose / D. Gałkowska, T. Fortuna, W.P. Zagórska //Potravinarstvo Slovak Journal of Food Sciences. 2010. — № 4(2). - P. 22-24.

2. Amaro L.F. Influence of cultivar and storage conditions in anthocyanin content and radical-scavenging activity of strawberry jams / L.F. Amaro, M.T. Soares, C. Pinho, I.F. Almeida, I. M. P. L. V. O. Ferreira, O. Pinho. World Academy of Science, Engineering and Technology. - 2012. - Vol. 69.

3. Kopjar M. Strawberry jams: influence of different pectins on colour and textural properties / V. Pilizota, N. N. Tiban, D. Subaric, J. Babic, D. Ackar, M. Sajdl // Czech J Food Sci. - 2009. - № 27(1). - P. 20-28.

4. B'kowska-Barczak A. Acylated anthocyanins as stable, natural food colorants - a review / A. B ${ }^{1}$ kowska-Barczak // Polish journal of food and nutrition sciences. - 2005. — Vol. 14/55. № 2. - P. 107-116.

5. Garcia-Viguera $C$. Color stability of strawberry jam as affected by cultivar and storage temperature / C. García-Viguera, P. Zafrilla, F. Romero, P. Abellán, F. Artés, F.A. Tomás-Barberán //Journal of Food Science. — 1999. — № 64(2). — P. 243-247.

6. Tangen K.O.G. Quality of fruits and purees of strawberries as affected by genotype, maturity and processing/ K.O.G. Tangen. Ås: UMB. — 2013. — P. 47.

7. Avasoo M. Evaluation of thermal processing technologies for strawberry jam/ M. Avasoo, L. Johansson — 2011 [Електронний ресурc]. — Режим доступу : http://ukkpfhd.livsmedelsakademin.se/sites/default/files/media/evaluation_of_thermal_processing_technologies_fo r_strawberry_jam.final_.pdf.

8. Garcia E. Preservative treatments for fresh-cut fruits and vegetables / E. Garcia, D.M. Barrett // Fresh-cut fruits and vegetables. - 2002. - P. 267-304.

9. Kader A.A. Postharvest technology of horticultural crops / A.A. Kader. University of California Agriculture and Natural Resources. - 2002. - T. 3311.

10. Tangen K.O.G. Quality of fruits and purees of strawberry as affwcted by genotype, maturity and processing / K.O.G. Tangen. Master's thesis, Norwegian University of Life Sciences, Ås. - 2013.

11. Abers J.E. Causative factors of color deterioration in strawberry preserves during processing and storage / J.E. Abers (Doctoral dissertation). — 1977. 